Review

\title{
Embodied carbon mitigation and reduction in the built environment - What does the evidence say?
}

\author{
Francesco Pomponi *, Alice Moncaster \\ Department of Engineering, University of Cambridge, Trumpington Street, CB21PZ Cambridge, UK
}

\section{A R T I C L E I N F O}

Article history:

Received 29 March 2016

Received in revised form 21 June 2016

Accepted 11 August 2016

Available online $\mathrm{xxx}$

Keywords:

Embodied carbon reduction

Embodied carbon mitigation

Low carbon built environment

LCA buildings

\section{A B S T R A C T}

Of all industrial sectors, the built environment puts the most pressure on the natural environment, and in spite of significant efforts the International Energy Agency suggests that buildings-related emissions are on track to double by 2050. Whilst operational energy efficiency continues to receive significant attention by researchers, a less well-researched area is the assessment of embodied carbon in the built environment in order to understand where the greatest opportunities for its mitigation and reduction lie. This article approaches the body of academic knowledge on strategies to tackle embodied carbon (EC) and uses a systematic review of the available evidence to answer the following research question: how should we mitigate and reduce EC in the built environment? 102 journal articles have been reviewed systematically in the fields of embodied carbon mitigation and reduction, and life cycle assessment. In total, 17 mitigation strategies have been identified from within the existing literature which have been discussed through a meta-analysis on available data Results reveal that no single mitigation strategy alone seems able to tackle the problem; rather, a pluralistic approach is necessary. The use of materials with lower EC, better design, an increased reuse of EC-intensive materials, and stronger policy drivers all emerged as key elements for a quicker transition to a low carbon built environment. The meta-analysis on 77 LCAs also shows an extremely incomplete and short-sighted approach to life cycle studies. Most studies only assess the manufacturing stages, often completely overlooking impacts occurring during the occupancy stage and at the end of life of the building. The LCA research community have the responsibility to address such shortcomings and work towards more complete and meaningful assessments.

(C) 2016 Published by Elsevier Ltd.

\section{Introduction and theoretical background}

Of all industrial sectors, the built environment puts the most pressure on the natural environment. In the European Union, it accounts for $50 \%$ of all extracted materials, $42 \%$ of the final energy consumption, $35 \%$ of greenhouse gases (GHGs) emissions (EC, 2011) and 32\% of waste flows (EEA, 2012), and global figures are not much different (Khasreen et al., 2009). To manage the environment sustainably, the role of the built, and particularly the urban, environment is crucial. Cities occupy only $3 \%$ of the Earth's land but account for around $70 \%$ of energy consumption and carbon dioxide emissions

\footnotetext{
* Corresponding author.

Email address: fp327@cam.ac.uk (F. Pomponi)
}

(UN, 2016). While buildings provide the essential infrastructure for civilization and our need for shelter, they also create an ecological threat in terms of resource consumption and depletion, air quality, and pollution of soil and water (Naustdalslid, 2014).

Considerable effort across policy, academia and industry has therefore gone into improving the energy efficiency of buildings. Until recently political effort has focused almost entirely on the operational stage (occupancy phase) of buildings, with one example being the European Union final deadline for nearly Zero Energy Buildings (nZEB) from 2020 (EU, 2010). The reason given for this focus is that operational energy (and carbon) accounts for the greatest share of life cycle energy (and carbon) of a building.

In spite of these efforts $\mathrm{CO}_{2}$ emissions are continuing to rise, with the International Energy Agency (IEA) suggesting that emissions are 
on track to double by 2050 (IEA, 2014). Part of the reason appears to be that the higher energy efficiency leads to rebound effects from increased energy demand, due to, for instance, "more heated space, higher temperatures, and for longer periods" (Rovers, 2014). However a less well-researched reason may be due to the unnecessary dichotomy between operational and embodied impacts, which has the unintended consequences both of ignoring the effects of increased construction and in some cases of shifting the environmental burdens from one life cycle stage (occupancy) to the others (Pomponi et al., 2016a). There is now robust evidence that the embodied impacts of buildings are a significant contributor to global emissions, and that as a percentage of whole life impacts of buildings they can account for more than 50\% (Crawford, 2011), with 70\% calculated for some cases in the UK (Ibn-Mohammed et al., 2013).

Out of several potential measures, 'embodied carbon equivalent' $\left(\mathrm{CO}_{2 \mathrm{e}}{ }^{1}\right)$ is useful for several relevant reasons:

- It measures and indicates the contribution of buildings and their products to global warming and climate change, which is increasingly critical (Moncaster, 2015; IPCC, 2014);

- Through considering the carbon intensity of the energy carrier it is more comprehensive than embodied energy (Pomponi et al., 2015);

- While it may not accurately represent additional ecological and environmental impacts (Pomponi et al., 2016a; Asdrubali et al., 2015a; Turconi et al., 2013), it correlates well with several impact categories of more comprehensive impact assessment methods (e.g. ReCiPe) (Heinonen et al., 2016), thus acting as a useful indicator for impacts other than climate change.

The substantial growth of related literature from outside academia (ASPB, 2014; RICS, 2012; UKGBC, 2015; IEA, 2016; ICE, 2015; BRE, 2015) which address the themes of EC reduction and mitigation also confirms the importance of embodied carbon.

In spite of this growing interest and understanding of the issue, the body of academic knowledge on strategies to tackle embodied carbon has not previously been investigated systematically. This article addresses this shortcoming and uses a systematic review of the academic evidence to answer the following research question: how should we mitigate and reduce, embodied carbon in the built environment? The following section introduces the method whereas section three discusses each of the mitigation strategies identified and provides a synopsis of the reviewed literature in table form. Section four includes the meta-analysis of all collected data to identify existing trends and issues. It also discusses the outcomes of the systematic review and identifies the most pressing issues which demand close attention. Section five concludes the article.

\section{Method}

The systematic approach used to review the existing literature ensures thoroughness, rigour and objectivity in the selected studies. This approach is widely used in medical and management sciences (Tranfield et al., 2003; Delbufalo, 2012) but also in built environment research (Pomponi et al., 2016b). A further technique often combined with this process is the meta-analysis of data to quantitatively integrate research findings across a wide number of studies (Delbufalo,

\footnotetext{
${ }^{1}$ Defined as the sum of $\mathrm{CO}_{2 \mathrm{eq}}$ emissions related to all activities and components other than the operational energy consumption related to a building's life. More generally, embodied costs or impacts may refer to different units such as energy, carbon, water, natural resource depletion, etc. Carbon dioxide equivalent emissions are also the measuring unit of the Global Warming Indicator (GWI).
}

2012) in order to reveal and map significant trends (Pomponi et al., 2016b) through the harmonised use of reviewed data (Asdrubali et al., 2015a; Pomponi et al., 2016b). Ultimately, the purpose of a systematic literature review and meta-analysis is to make sense of key elements within a large collection of sometimes-contradictory studies to facilitate decision-making and action with an aim to inform both policymaking and practice (Tranfield et al., 2003).

In this article the following strings ${ }^{2}$ and combinations thereof have been searched across main literature database ${ }^{3}$ :

- Embodied carbon mitigation (+strategy)

- Embodied carbon reduction (+strategy)

- Embodied carbon management (+strategy)

- Embodied carbon building(s)

- Life cycle assessment building(s)

- LCA building(s)

- Life cycle carbon building(s)

Due to the rapidly developing field, search results were temporally limited to 10 years and given existing disputes over reliability, data quality, and system boundaries within LCA, results were also limited to peer-reviewed journal articles. In total, after manually removing duplicates due to the different search engines used, 876 manuscripts matched the initial search criteria. The abstracts of these papers were then reviewed for a second selection round which resulted in 229 articles, due to the key words being mentioned in different parts of the abstracts without any connection. These 229 were analysed in depth, and 102 were identified to fall within the remit of the present work, which included sufficient information for the scope of this study with respect to embodied carbon mitigation and reduction in the built environment and enough detail on the LCA study, where this was undertaken.

The research question asks, how should we mitigate and reduce embodied carbon in the built environment? To answer this, the following elements were identified from the studies:

(1) Mitigation strategies: first as they arose from the articles and then coded into consistent and coherent clusters;

(2) The geographical breadth of the study (GA), rated 0 to 3 , where 0 is a study not related to a geographical area and 1 to 3 instead cover super-country, country, and sub-country levels respectively;

(3) The scale of the study (SS), rated 0 to 3 , where 0 is a study related to, for instance, a whole neighbourhood and 1 to 3 cover context (i.e. building), system (e.g. façade), and component (e.g. brick) levels;

(4) The life cycle stages included in the analysis, mapped using the framework developed by the European Technical Committee TC350 (BSI, 2011) (Fig. 1).

Regarding the latter point, not all the studies allowed for a thorough mapping of life cycle stages and therefore this specific analysis is limited to 77 articles which are more of an LCA nature out of the 102 reviewed. 2 The search was limited to Title, Abstract, and Keywords of manuscripts to avoid
completely unrelated results.

${ }^{3}$ Web of Knowledge, Web of Science, Science Direct and Google Scholar. 


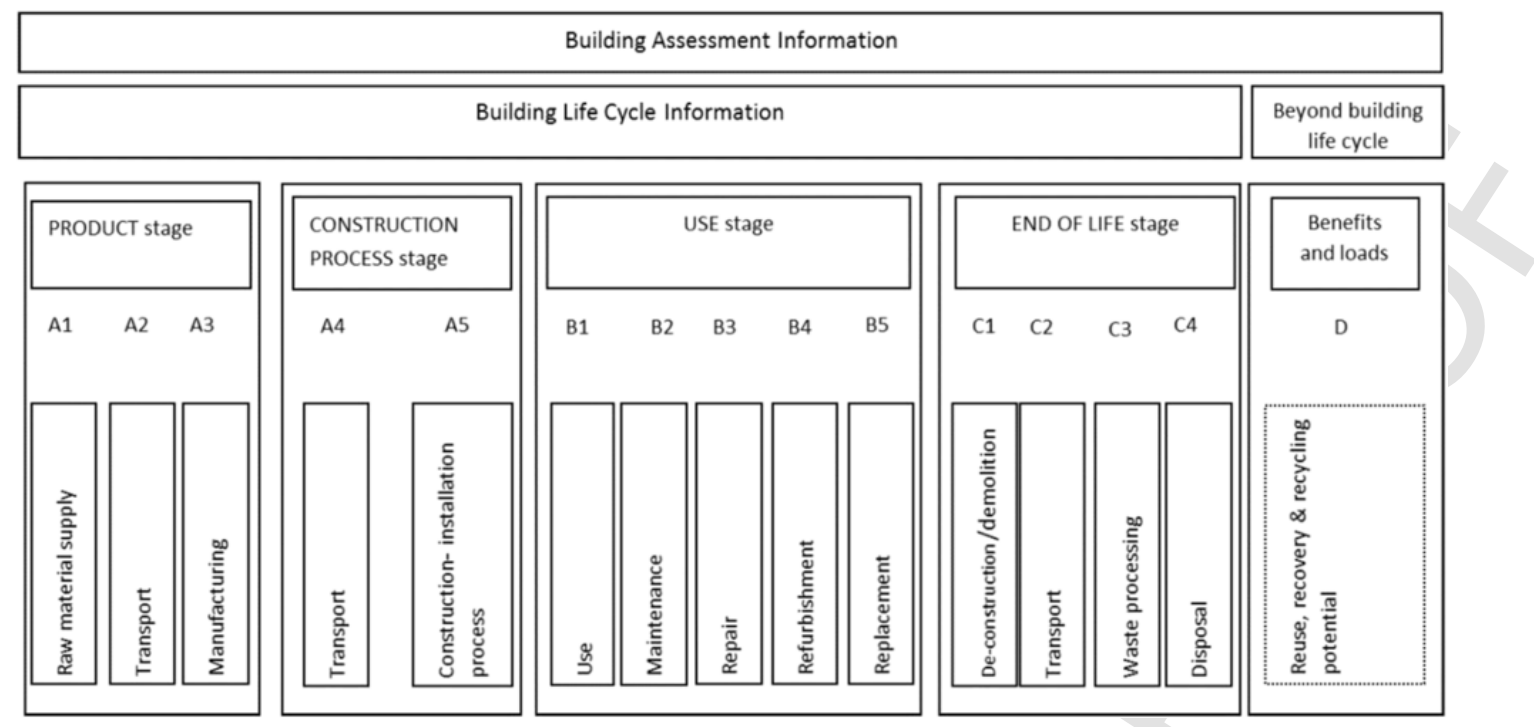

Fig. 1. Life cycle stages of a building (BS EN 15978:2011).

\section{Embodied carbon mitigation strategies}

Seventeen mitigation strategies (MSs) were identified in the reviewed literature, and these are presented in Table 1. MSs were defined progressively along with the review of all articles. For instance, MS1 was the first to be defined as the first paper we reviewed recommended a greater use of wood as a construction to reduce EC in buildings. Table 2 then details each of the 102 articles with the four elements of analysis: the mitigation strategies (numbered as given in Table 1); the geographical breadth of the study (GA); the scale of the study (SS); and the life cycle stages included (as identified within BS EN 15978). The articles are listed in chronological order of access. The sub-sections following these tables take each mitigation strategy in turn and discuss it with reference to a few specific papers.

\subsection{MS1: use of materials with lower embodied energy and carbon}

The use of alternative materials with low EE and EC to mitigate the contribution of the built environment to climate change was a particularly common solution (e.g. Yu et al., 2011; Ng et al., 2012). In many studies, this approach involves the use of natural materials (e.g.

Table 1

Details of the mitigation strategies (MSs) identified in the literature.

\begin{tabular}{ll}
\hline MS & Description \\
\hline 1 & Practical guidelines for a wider use of low-EC materials \\
2 & Better design \\
3 & Reduction, re-use and recovery of EE/EC intensive construction materials \\
4 & Tools, methods, and methodologies \\
5 & Policy and regulations (Governments) \\
6 & Refurbishment of existing buildings instead of new built \\
7 & Decarbonisation of energy supply/grid \\
8 & Inclusion of waste, by-product, used materials into building materials \\
9 & Increased use of local materials \\
10 & Policy and regulations (Construction sector) \\
11 & People-driven change (key role of all BE stakeholders) \\
12 & More efficient construction processes/techniques \\
13 & Carbon mitigation offsets, emissions trading, and carbon tax \\
14 & Carbon sequestration \\
15 & Extending the building's life \\
16 & Increased use of prefabricated elements/off-site manufacturing \\
17 & Demolition and rebuild \\
\hline
\end{tabular}

timber, bamboo, hemp-lime composites). For instance, Reddy (Reddy, 2009) investigated the use of stabilised mud blocks (SMB) as a substitute for load bearing brickwork and found nearly a $50 \%$ reduction in embodied costs. With a focus on using alternative building materials over more traditional ones for a 28-storey residential building in Hong Kong, Cui and colleagues (Cui et al., 2011) quantified the related embodied carbon savings, obtaining a $34.8 \%$ reduction. Switching from material level to a full house project, Salazar and Meil (Salazar and Meil, 2009) assessed the GHG impacts of what they call a 'wood-intensive' house in comparison to a typical one with brick cladding in Canada and found extremely significant differences between the two: $20 \mathrm{tCO}_{2 \mathrm{e}}$ for the former vs. $72 \mathrm{tCO}_{2 \mathrm{e}}$ of the latter. The enormous potential of a broader adoption of wood as a construction material seems confirmed by Upton and colleagues (Upton et al., 2008) who, in a US residential-sector-wide study, indicated savings of $9.6 \mathrm{MtCO}_{2 \mathrm{e} / \mathrm{annum}}$ by using wood as an alternative to concrete- and steel-based building systems under the assumption of 1.5 million single-family new houses built each year. Vukotic and colleagues (Vukotic et al., 2010) also found a timber structure school building to have lower impacts than the steel frame alternative, but recommend that "rather than encouraging debate about which material is 'better' than any other", the best use is made of chosen materials in any particular situation (Vukotic et al., 2010). It is worth noting that in some comparative studies, the use of materials with lower EE/EC may also involve commonly-used materials, such as in the work of You and colleagues (You et al., 2011) who found a $4.2 \% \mathrm{CO}_{2}$ reduction in preferring steel-concrete structures over masonry-concrete structures; an aspect which leads to the importance of design discussed in the next sub-section.

\subsection{MS2: better design}

Good design practice and appropriate choices at the design stage, as well as techniques such as design for deconstruction, were identified as crucial strategies for EC reduction and mitigation. Acquaye and Duffy (Acquaye and Duffy, 2010) conducted an input-output analysis of the Irish construction sector; they suggest that their results showed that better design could have reduced indirect emissions by $20 \%$ and direct emissions by $1.6 \%$ totalling $3.43 \mathrm{MtCO}_{2 \mathrm{e}}$. In examining refurbishment of high-rise concrete buildings in Hong Kong, 
Table 2

Data Collected from the systematic review of the literature.

\begin{tabular}{|c|c|c|c|c|c|c|c|c|c|c|c|c|c|c|c|c|c|c|c|c|c|c|c|c|c|c|c|c|c|c|c|c|c|c|c|c|c|c|c|c|}
\hline Ref. & & tiga & on $\mathrm{s}$ & trate & gies & & & & & & & & & & & & & GA & & & & SS & & & & & EN 15 & 978:2 & 20111 & life cy & ycle st & ages & & & & & & & & \\
\hline & 1 & 2 & 3 & 4 & 5 & 6 & 7 & 8 & 9 & 10 & 11 & 12 & 13 & 14 & 15 & 16 & 17 & 0 & 1 & 2 & 3 & 0 & 1 & 2 & 3 & $\mathrm{~A} 1$ & A2 & A3 & A4 & A5 & $\mathrm{B} 1$ & B2 & B3 & B4 & B5 & $\mathrm{C} 1$ & $\mathrm{C} 2$ & $\mathrm{C} 3$ & $\mathrm{C} 4$ & $\mathrm{D}$ \\
\hline (Gustavsson et al., 2006) & $\mathrm{x}$ & & & & & & & & & & & & & $\mathrm{x}$ & & & & & $\mathrm{x}$ & $\mathrm{x}$ & & & $\mathrm{x}$ & & & $\mathrm{x}$ & & $\mathrm{x}$ & & $x$ & & & & & & $\mathrm{x}$ & & & & \\
\hline (Gustavsson and Sathre, 2006) & $\mathrm{x}$ & & & & & & $\mathrm{x}$ & & & & & & & & & & & & & $\mathrm{x}$ & & & & & $\mathrm{x}$ & $\mathrm{x}$ & $\mathrm{x}$ & $\mathrm{x}$ & $\mathrm{x}$ & $\mathrm{x}$ & & & & & & $\mathrm{x}$ & $\mathrm{x}$ & & & \\
\hline (Norman et al., 2006) & & $\mathrm{x}$ & $\mathrm{x}$ & & & & $\mathrm{x}$ & & $\mathrm{x}$ & & & & & & & & & & & & $\mathrm{x}$ & $\mathrm{x}$ & & & & $\mathrm{x}$ & $\mathrm{x}$ & $\mathrm{x}$ & & & $\nu$ & & & & & & & & & \\
\hline (Boardman, 2007) & & $\mathrm{x}$ & & & $\mathrm{x}$ & $\mathrm{x}$ & & & & & $\mathrm{x}$ & & & & & & $\mathrm{x}$ & & & $\mathrm{x}$ & & & $\mathrm{x}$ & & $\mathrm{x}$ & 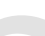 & & & & & & & & & & & & & & \\
\hline (Ardente et al., 2008) & $\mathrm{x}$ & & & & & & & & & & & & & & & & & & $\mathrm{x}$ & $\mathrm{x}$ & & & & & $\mathrm{x}$ & $\mathrm{x}$ & $\mathrm{x}$ & $\mathrm{x}$ & $\mathrm{x}$ & & & & & & & & & & $\mathrm{x}$ & \\
\hline (Power, 2008) & & & $\mathrm{x}$ & & & $\mathrm{x}$ & & & & & & & & & & & & & & $\mathrm{x}$ & & & $\mathrm{x}$ & & 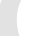 & & ( & & & & & & & & & & & & & \\
\hline (Roberts, 2008) & & & $\mathrm{x}$ & & & & & & & & & $\mathrm{x}$ & & & & $\mathrm{x}$ & & & & $\mathrm{x}$ & & & $\mathrm{x}$ & & $\mathrm{x}$ & & & & & & & & & & & & & & & \\
\hline (Upton et al., 2008) & $\mathrm{x}$ & $\mathrm{x}$ & & & & & & & & & & & & & & & & & & $\mathrm{x}$ & & $\mathrm{x}$ & $\mathrm{x}$ & & $\mathrm{x}$ & $\mathrm{x}$ & $\mathrm{x}$ & $\mathrm{x}$ & $\mathrm{x}$ & $\mathrm{x}$ & & & & & & & & & $\mathrm{x}$ & \\
\hline (Xing et al., 2008) & & & $\mathrm{x}$ & $\mathrm{x}$ & & & & & & & & & & & & & & & & $\mathrm{x}$ & & & 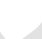 & & $\mathrm{x}$ & $\mathrm{x}$ & $\mathrm{x}$ & $\mathrm{x}$ & & & & & & & & & & & $\mathrm{x}$ & $\mathrm{x}$ \\
\hline (Jiang and Tovey, 2009) & & & & $\mathrm{x}$ & & & $\mathrm{x}$ & & & & $\mathrm{x}$ & & $\mathrm{x}$ & & & & & & & $\mathrm{x}$ & a & $\mathrm{x}$ & 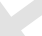 & & (a) & & & & & & & & & & & & & & & \\
\hline (Lee et al., 2009) & & & & $\mathrm{x}$ & & & & & & & & & & & & & & & & $\mathrm{x}$ & & & $\mathrm{x}$ & & & $\mathrm{x}$ & $\mathrm{x}$ & $\mathrm{x}$ & $\mathrm{x}$ & & & $\mathrm{x}$ & & & $\mathrm{x}$ & $\mathrm{x}$ & $\mathrm{x}$ & & & \\
\hline (Li and Colombier, 2009) & & $\mathrm{x}$ & & & $\mathrm{x}$ & $\mathrm{x}$ & $\mathrm{x}$ & & & $\mathrm{x}$ & & $\mathrm{x}$ & $\mathrm{x}$ & & & & & & & $\mathrm{x}$ & 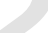 & $\mathrm{x}$ & ( & & & $\mathrm{x}$ & $\mathrm{x}$ & $\mathrm{x}$ & $\mathrm{x}$ & $\mathrm{x}$ & & & & & & $\mathrm{x}$ & & & & $\mathrm{x}$ \\
\hline (Reddy, 2009) & $\mathrm{x}$ & & $\mathrm{x}$ & & & & $\mathrm{x}$ & $\mathrm{x}$ & $\mathrm{x}$ & & $\mathrm{x}$ & & & & & & & & & $\mathrm{x}$ & & & & & $\mathrm{x}$ & $\mathrm{x}$ & $\mathrm{x}$ & $\mathrm{x}$ & $\mathrm{x}$ & $\mathrm{x}$ & & & & & & & & & & \\
\hline (Salazar and Meil, 2009) & $\mathrm{x}$ & & $\mathrm{x}$ & & & & & & & & & & & $\mathrm{x}$ & & & & & $\mathrm{x}$ & $\mathrm{x}$ & ( & & $\mathrm{x}$ & & & $\mathrm{x}$ & $\mathrm{x}$ & $\mathrm{x}$ & & & & & & & & & & $\mathrm{x}$ & $\mathrm{x}$ & \\
\hline (Acquaye and Duffy, 2010) & $\mathrm{x}$ & $\mathrm{x}$ & & $\mathrm{x}$ & & & & & & $\mathrm{x}$ & & & & & & & & & & $\mathrm{x}$ & & & $\mathrm{x}$ & & & $\mathrm{x}$ & & $\mathrm{x}$ & & & & & & & & & & & & \\
\hline (Dhakal, 2010) & & & & & $\mathrm{x}$ & & & & & & & & & & & & & $\mathrm{x}$ & & & & $\mathrm{x}$ & & & & & & & & & & & & & & & & & & \\
\hline (Blengini and Di Carlo, 2010) & & & $\mathrm{x}$ & & $\mathrm{x}$ & & & & & & & & & & & & & & & $\mathrm{x}$ & $\mathrm{x}$ & $\mathrm{x}$ & & & & $\mathrm{x}$ & $\mathrm{x}$ & $\mathrm{x}$ & $\mathrm{x}$ & $\mathrm{x}$ & & $\mathrm{x}$ & & & & $\mathrm{x}$ & & & $\mathrm{x}$ & \\
\hline (Gustavsson et al., 2010) & $\mathrm{x}$ & & & & & & & $\mathrm{x}$ & $\mathrm{x}$ & & & & & & & & & & & $\mathrm{x}$ & & & $\mathrm{x}$ & $\mathrm{x}$ & $\mathrm{x}$ & $\mathrm{x}$ & $\mathrm{x}$ & $\mathrm{x}$ & & $\mathrm{x}$ & & & & & & $\mathrm{x}$ & & & & $\mathrm{x}$ \\
\hline (Power, 2010) & & & $\mathrm{x}$ & & & $\mathrm{x}$ & & & & & & & & & & & & & & & & & & & & & & & & & & & & & & & & & & \\
\hline (Seyfang, 2010) & $\mathrm{x}$ & & & & $\mathrm{x}$ & & & & & & & & & & & & & & $\mathrm{x}$ & $\mathrm{x}$ & & & $\mathrm{x}$ & & & & & & & & & & & & & & & & & \\
\hline (Vukotic et al., 2010) & $\mathrm{x}$ & $\mathrm{x}$ & $\mathrm{x}$ & & & & & & $\mathrm{x}$ & & & & & & $\mathrm{x}$ & $\mathrm{x}$ & & & & $\mathrm{x}$ & & & & & $\mathrm{x}$ & $\mathrm{x}$ & $\mathrm{x}$ & $\mathrm{x}$ & $\mathrm{x}$ & $\mathrm{x}$ & & $\mathrm{x}$ & $\mathrm{x}$ & & & $\mathrm{x}$ & $\mathrm{x}$ & & $\mathrm{x}$ & $\mathrm{x}$ \\
\hline (Acquaye et al., 2011) & & $\mathrm{x}$ & & & $\mathrm{x}$ & & & & & & & & & & & & & & $\mathrm{x}$ & $\mathrm{x}$ & & & $\mathrm{x}$ & & & & & & & & & & & & & & & & & \\
\hline (Bribián et al., 2011) & $\mathrm{x}$ & $\mathrm{x}$ & & & $\mathrm{x}$ & & $\mathrm{x}$ & & & & & & ( & & & & & & & $\mathrm{x}$ & & & & & $\mathrm{x}$ & $\mathrm{x}$ & $\mathrm{x}$ & $\mathrm{x}$ & $\mathrm{x}$ & & & & & & & $\mathrm{x}$ & & $\mathrm{x}$ & & $\mathrm{x}$ \\
\hline (Chang et al., 2011) & & & & & & & $\mathrm{x}$ & & & & & & & & & & & & & $\mathrm{x}$ & & & $\mathrm{x}$ & & & & & & & & & & & & & & & & & \\
\hline (Crishna et al., 2011) & & & & & & & & & & & & & & & & & & & & $\mathrm{x}$ & $\mathrm{x}$ & & & & $\mathrm{x}$ & $\mathrm{x}$ & $\mathrm{x}$ & $\mathrm{x}$ & $\mathrm{x}$ & & & & & & & & & & & \\
\hline (Dakwale et al., 2011) & $\mathrm{x}$ & $\mathrm{x}$ & & & $\mathrm{x}$ & & $\mathrm{x}$ & & & & & $\mathrm{x}$ & & & & & & $\mathrm{x}$ & & & & & $\mathrm{x}$ & $\mathrm{x}$ & $\mathrm{x}$ & $\mathrm{x}$ & & $\mathrm{x}$ & & & & & & & & & & & & \\
\hline (Heinonen et al., 2011) & $\mathrm{x}$ & $\mathrm{x}$ & & & & $\mathrm{x}$ & $\mathrm{x}$ & & & & & $\mathrm{x}$ & & & & & & & & $\mathrm{x}$ & & $\mathrm{x}$ & & & & $\mathrm{x}$ & & $\mathrm{x}$ & & $\mathrm{x}$ & $\mathrm{x}$ & $\mathrm{x}$ & $\mathrm{x}$ & & & & & $\mathrm{x}$ & $\mathrm{x}$ & \\
\hline (Intini and Kuehtz, 2011) & & & & & & & & & & & & & & & & & & & & $\mathrm{x}$ & & & & & $\mathrm{x}$ & $\mathrm{x}$ & $\mathrm{x}$ & $\mathrm{x}$ & & & & & & & & & & & & \\
\hline (Kennedy and Sgouridis, 2011) & & $\mathrm{x}$ & & & $\mathrm{x}$ & 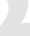 & $\mathrm{x}$ & & & $\mathrm{x}$ & & & $\mathrm{x}$ & & & & & $\mathrm{x}$ & & & & $\mathrm{x}$ & & & & $\mathrm{x}$ & & $\mathrm{x}$ & & $\mathrm{x}$ & & & & & & & & $\mathrm{x}$ & $\mathrm{x}$ & \\
\hline (Lee et al., 2011) & & & & & & & & & & & & & & & & & & & & & & & & & $\mathrm{x}$ & $\mathrm{x}$ & $\mathrm{x}$ & $\mathrm{x}$ & $\mathrm{x}$ & & & & & & & & & & & \\
\hline (Monahan and Powell, 2011) & $\mathrm{x}$ & 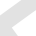 & 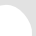 & & t & & & & & & & $\mathrm{x}$ & & & & $\mathrm{x}$ & & & & $\mathrm{x}$ & & & $\mathrm{x}$ & & $\mathrm{x}$ & $\mathrm{x}$ & $\mathrm{x}$ & $\mathrm{x}$ & $\mathrm{x}$ & $\mathrm{x}$ & & & & & & & & & & \\
\hline (Sodagar et al., 2011) & $\mathrm{x}$ & $\mathrm{x}$ & 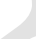 & & 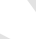 & 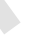 & & & & & & & & $\mathrm{x}$ & & & & & & $\mathrm{x}$ & & & $\mathrm{x}$ & & & $\mathrm{x}$ & $\mathrm{x}$ & $\mathrm{x}$ & & & & & & & & & & & & \\
\hline (Densley Tingley and Davison, 2011) & $\mathrm{x}$ & $\mathrm{x}$ & $\mathrm{x}$ & $\mathrm{x}$ & 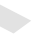 & & $\mathrm{x}$ & $\mathrm{x}$ & & & & & $\mathrm{x}$ & $\mathrm{x}$ & $\mathrm{x}$ & & & $\mathrm{x}$ & & & & & $\mathrm{x}$ & & $\mathrm{x}$ & & & & & & & & & & & & & & & \\
\hline (Toller et al., 2011) & $\mathrm{x}$ & 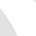 & $\mathrm{x}$ & $\mathrm{x}$ & & $\mathrm{x}$ & & & $\mathrm{x}$ & & & & & & $\mathrm{x}$ & & & & & $\mathrm{x}$ & & $\mathrm{x}$ & & & & & & & & & & & & & & & & & & \\
\hline (Yeo and Gabbai, 2011) & & $\mathrm{x}$ & $\mathrm{x}$ & & & & & & & & & & & & & & & & & $\mathrm{x}$ & & & & & $\mathrm{x}$ & $\mathrm{x}$ & $\mathrm{x}$ & $\mathrm{x}$ & & & & & & & & & & & & \\
\hline (You et al., 2011) & $\mathrm{x}$ & & $\mathrm{x}$ & & & & & & $\mathrm{x}$ & & & & & & & & & & & $\mathrm{x}$ & & $\mathrm{x}$ & $\mathrm{x}$ & & & $\mathrm{x}$ & $\mathrm{x}$ & $\mathrm{x}$ & & $\mathrm{x}$ & & & & $\mathrm{x}$ & $\mathrm{x}$ & $\mathrm{x}$ & & $\mathrm{x}$ & & $\mathrm{x}$ \\
\hline (Yu et al., 2011) & $\mathrm{x}$ & & $\mathrm{x}$ & & & & & $\mathrm{x}$ & & & & & & & & & & & & $\mathrm{x}$ & & & $\mathrm{x}$ & $\mathrm{x}$ & $\mathrm{x}$ & $\mathrm{x}$ & $\mathrm{x}$ & $\mathrm{x}$ & $\mathrm{x}$ & $\mathrm{x}$ & & & & & & $\mathrm{x}$ & & $\mathrm{x}$ & $\mathrm{x}$ & $\mathrm{x}$ \\
\hline (Cui et al., 2011) & $\mathrm{x}$ & & $\mathrm{x}$ & & & & & & & & & & & & & & & & & $\mathrm{x}$ & & & & & $\mathrm{x}$ & $\mathrm{x}$ & $\mathrm{x}$ & $\mathrm{x}$ & & & & & & & & & & & & \\
\hline (Chau et al., 2012) & $\mathrm{x}$ & $\mathrm{x}$ & $\mathrm{x}$ & & & $\mathrm{x}$ & & & & & & & & & & & & & & $\mathrm{x}$ & & & & $\mathrm{x}$ & $\mathrm{x}$ & $\mathrm{x}$ & $\mathrm{x}$ & $\mathrm{x}$ & & & & $\mathrm{x}$ & & & $\mathrm{x}$ & & & $\mathrm{x}$ & & $\mathrm{x}$ \\
\hline (Cuéllar-Franca and Azapagic, 2012) & & $\mathrm{x}$ & $\mathrm{x}$ & & & & & & & & & & & & & & & & & $\mathrm{x}$ & & & $\mathrm{x}$ & & & & & & & $\mathrm{x}$ & & & & & & $\mathrm{x}$ & & $\mathrm{x}$ & & $\mathrm{x}$ \\
\hline (Culakova et al., 2012) & $\mathrm{x}$ & & & & & & & & & & & & & & & & & & & $\mathrm{x}$ & & & $\mathrm{x}$ & & & $\mathrm{x}$ & $\mathrm{x}$ & $\mathrm{x}$ & & & & & & & & & & & & \\
\hline (Dalene, 2012) & & & & & & & & & & & & & $\mathrm{x}$ & & & & & & & $\mathrm{x}$ & & & $\mathrm{x}$ & & & $\mathrm{x}$ & & & $\mathrm{x}$ & $\mathrm{x}$ & & & & & & $\mathrm{x}$ & & & $\mathrm{x}$ & $\mathrm{x}$ \\
\hline (Gong et al., 2012) & $\mathrm{x}$ & $\mathrm{x}$ & $\mathrm{x}$ & & & & $\mathrm{x}$ & & & & & & & & & & & & & $\mathrm{x}$ & $\mathrm{x}$ & & $\mathrm{x}$ & $\mathrm{x}$ & $\mathrm{x}$ & $\mathrm{x}$ & $\mathrm{x}$ & $\mathrm{x}$ & $\mathrm{x}$ & $\mathrm{x}$ & & & & & & $\mathrm{x}$ & & & & \\
\hline (Dixit et al., 2012) & $\mathrm{x}$ & & & $\mathrm{x}$ & & & & & & & & & & & & & & $\mathrm{x}$ & & & & $\mathrm{x}$ & $\mathrm{x}$ & $\mathrm{x}$ & & & & & & & & & & & & & & & & \\
\hline (Moncaster and Song, 2012) & & & & $\mathrm{x}$ & $\mathrm{x}$ & & & & $\mathrm{x}$ & & & & & & & & & $\mathrm{x}$ & & & & $\mathrm{x}$ & & & & & & & & & & & & & & & & & & \\
\hline (Ng et al., 2012) & $\mathrm{x}$ & $\mathrm{x}$ & $\mathrm{x}$ & & & & & $\mathrm{x}$ & & & & & & & $\mathrm{x}$ & & & $\mathrm{x}$ & & & & $\mathrm{x}$ & & & $\mathrm{x}$ & & & & & & & & & & & & & & & \\
\hline (Purnell, 2012) & $\mathrm{x}$ & $\mathrm{x}$ & $\mathrm{x}$ & $\mathrm{x}$ & & & & & & & & & & & & & & $\mathrm{x}$ & & & & & & & $\mathrm{x}$ & $\mathrm{x}$ & $\mathrm{x}$ & $\mathrm{x}$ & $\mathrm{x}$ & & & & & & & & & & & \\
\hline (Rossi et al., 2012) & & & $\mathrm{x}$ & & & & & & & & & & & & & & & $\mathrm{x}$ & & & & & $\mathrm{x}$ & & $\mathrm{x}$ & $\mathrm{x}$ & $\mathrm{x}$ & $\mathrm{x}$ & $\mathrm{x}$ & & & & & & & & & & & \\
\hline (Song et al., 2012) & $\mathrm{x}$ & $\mathrm{x}$ & & & & & $\mathrm{x}$ & & & & & & & & & & & & & $\mathrm{x}$ & $\mathrm{x}$ & & $\mathrm{x}$ & & & & & & & & & & & & & & & & & \\
\hline (Bin and Parker, 2012) & $\mathrm{x}$ & & $\mathrm{x}$ & & & $\mathrm{x}$ & & & & & & & & & & & & & & $\mathrm{x}$ & & & $\mathrm{x}$ & & & $\mathrm{x}$ & $\mathrm{x}$ & $\mathrm{x}$ & $\mathrm{x}$ & $\mathrm{x}$ & & & & & $\mathrm{x}$ & & & & & \\
\hline (Yung and Chan, 2012) & & & & & $\mathrm{x}$ & $\mathrm{x}$ & & & & & $\mathrm{x}$ & & & & $\mathrm{x}$ & & & & & $\mathrm{x}$ & & & $\mathrm{x}$ & & & & & & & & & & & & & & & & & \\
\hline (Basbagill et al., 2013) & & $\mathrm{x}$ & $\mathrm{x}$ & $\mathrm{x}$ & & & & & & & & & & & & & & & $\mathrm{x}$ & & & & & $\mathrm{x}$ & $\mathrm{x}$ & $\mathrm{x}$ & & $\mathrm{x}$ & & $\mathrm{x}$ & & $\mathrm{x}$ & $\mathrm{x}$ & $\mathrm{x}$ & & & & & & \\
\hline (Cabeza e & $\mathrm{x}$ & & $\mathrm{x}$ & & & & & & & & & & & & & & & $\mathrm{x}$ & & & & & & & $\mathrm{x}$ & $\mathrm{x}$ & & $\mathrm{x}$ & & & & & & & & & & $\mathrm{x}$ & & $\mathrm{x}$ \\
\hline (Baek et al., 2013) & & $\mathrm{x}$ & & $\mathrm{x}$ & & & & & & $\mathrm{x}$ & & & & & & & & & $\mathrm{x}$ & & & $\mathrm{x}$ & $\mathrm{x}$ & & & & & $\mathrm{x}$ & $\mathrm{x}$ & $\mathrm{x}$ & & $\mathrm{x}$ & & $\mathrm{x}$ & & $\mathrm{x}$ & $\mathrm{x}$ & & & \\
\hline
\end{tabular}


Chau and colleagues (Chau et al., 2012) also found a determinant role of design. They argued that "the most effective option is to maintain $15-30 \%$ of the existing structural and non-structural building elements as it can reduce the $\mathrm{CO}_{2}$ footprint by $17.3 \%$ ". This view is echoed and supported by Cuéllar-Franca and Azapagic (Cuéllar-Franca and Azapagic, 2012) who reflect on the longevity of decisions taken at the design stage and call for a sustainable home design which considers the impact that design choices exert over the building's life cycle. The centrality of design is also emphasised by Häkkinen and colleagues (Häkkinen et al., 2015) who recommend a gradual and systematic procession through all different phases and stages of design to accurately assess GHG emissions and achieve low-carbon buildings.

\subsection{MS3: reduction, re-use and recovery of EE/EC intensive construction materials}

Basbagill and colleagues (Basbagill et al., 2013) investigated in detail the application of LCA to help designers understand and reduce the environmental impacts of building materials and components. They found that by optimising key parameters (e.g. thickness of piles and footings, and of external and internal walls) "anywhere from $63 \%$ to $75 \%$ reduction in the building's maximum total embodied impact is possible" (Basbagill et al., 2013). Garcia-Segura and colleagues (Garcia-Segura et al., 2014) assessed the reduction of GHG emissions due to a reduced use of Portland cement and its substitution with blended cement, which has a higher content of fly ash (FA) and blast furnace slag (BFS). Such an approach promises to lead to $7 \%-20 \%$ fewer emissions (Garcia-Segura et al., 2014). Similar environmental benefits following a reduction in use of cement are echoed by Atmaca and Atmaca (Atmaca and Atmaca, 2015) and Miller and Doh (Miller and Doh, 2015). Moynihan and Allwood (Moynihan and Allwood, 2014) investigated the utilisation of structural steel in buildings and concluded that by designing to minimise the material used rather than the cost, the use of steel in building and the associated embodied impacts could be dramatically reduced.

\subsection{MS4: tools, methods, and methodologies}

Despite the populated panorama of existing tools, assessment methods and methodology, it still seems this is seen as a key area to bring about embodied carbon reduction with the parallel aim of building a better and stronger EC culture amongst the built environment stakeholders. This may take the form of coupling EC assessment with building information modelling (BIM) (Ariyaratne and Moncaster, 2014), as a form on information hub, or combining BIM with dynamic energy simulation tools (Peng, 2016), to achieve an overall balance between operational and embodied figures. In some other cases, new methodologies aim at refining existing ones by, for example, coupling a life cycle carbon assessment with an analysis of the value created by the specific activity/product under investigation (Li et al., 2013).

\subsection{MS5: policy and regulations (Governments)}

Perhaps unsurprisingly, the implementation and/or revision of policy and regulations by Governments also emerged as a commonly cited strategy for EC reduction (e.g. Blengini and Di Carlo, 2010; Dakwale et., 2011; Foraboschi et., 2014). In some studies (Giesekam et al., 2014) this strategy is mainly intended as a means to support other mitigation strategies, like a wider use of low EE/EC materials, whereas in others policy has a broader reach. For instance, Dhakal (Dhakal, 2010) reports on Chinese and Japanese contexts where a 50\% $\mathrm{CO}_{2}$ reduction could be achieved through the impact of policies on design and construction practices.

\subsection{MS6: refurbishment of existing buildings}

A few scholars believe the greatest opportunity for EC mitigation lies with the upkeep of existing buildings. This appears to be especially true in developed countries where the existing building stock forms the vast majority of the built environment. Gaspar and Santos (Gaspar and Santos, 2015) assessed the potential saving for a detached house in Portugal built in the late 1960s, concluding that refurbishment would be $22 \%$ more efficient than demolition and rebuild. A strong case for refurbishments can be also found in the work of Power, who demonstrated that the case for large scale demolitions "is greatly weakened" when considering EC as well as operational figures, for the EC of an average refurbishment project to bring an existing house up to modern standards is around one third of that of a new house (Power, 2008, 2010).

\subsection{MS7: decarbonisation of energy supply/grid}

Just as the idea of decarbonising the energy supply is seen as one pathway to operational-carbon-free buildings (Rovers, 2014), some scholars point out that there is the same opportunity for embodied costs (Jiang and Tovey, 2009; Chang et al., 2011; Heinonen et al., 2011). For instance, in the study from Heinonen and colleagues (Heinonen et al., 2011) a specific 'greener' energy mix would cut $6 \%$ off the total emissions figure.

\subsection{MS8: inclusion of waste, by-product, and used materials into} building materials

A further beneficial effect may be brought about by the inclusion of waste and by-products into building materials (e.g. Lee et al., 2011; Napolano et al., 2015), in light of cradle-to-cradle design and circular economy approaches which have recently received increased attention as a valid and viable alternative to the traditional linear make-use-dispose paradigm. Intini and Kuehtz (Intini and Kuehtz, 2011) investigated the use of recycled plastic bottles to manufacture thermal insulation in Italy and concluded that recycled polyethylene terephthalate (PET) can reduce environmental impact as much as $46 \%$ with respect to GWP. Some researchers also highlight the importance of considering the necessary supply chain to realise this (Densley Tingley and Davison, 2011).

\subsection{MS9: increased use of local materials}

Several studies reported the EC reduction due to an increased use of local materials which would reduce transportation impacts (e.g. Gustavsson et al., 2010; Asdrubali et.al., 2015b; Chou and Yeh, 2015). In a detailed assessment of stone production carried out in accordance to PAS2050 guidelines, Crishna and colleagues (Crishna et al., 2011) argued that depending on the stone type and the country of origin, the use of UK-based stones can save between $2 \%$ and $84 \%$ of the EC of stones sourced from abroad. It is also worth considering that such strategy would benefit local or national economies as well as the environment. 


\subsection{MS10: policy and regulations (construction sector)}

For some scholars, the strength of policies and regulations lies not (or at least not only) with governments but with bodies and stakeholders within the construction sectors (e.g. Acquaye and Duffy, 2010; Akbarnezhad et al., 2014). For instance, Alshamrani and colleagues (Alshamrani et al., 2014) developed an integrated LCA - LEED model for sustainability assessment and believe there would be positive consequences if it were voluntarily adopted and used in the construction sector.

\subsection{MS11: people-driven change (key role of all stakeholders in the built environment)}

This cluster groups 'social' elements for a built environment with lower EC, such as an aesthetic demand for "buildings [with] sustainable credentials" (Monahan and Powell, 2011), or solutions related to people's skills such as the contractors' ability to plan resources, their management skills and construction performance mentioned by Sandanayake and colleagues (Sandanayake et al., 2016). Also, social or cultural aspects have been identified as barriers to EC reduction, such as the inertia of builders towards environmentally conscious regulations in China reported by $\mathrm{Li}$ and Colombier ( $\mathrm{Li}$ and Colombier, 2009).

\subsection{MS12: more efficient construction processes/techniques}

In some studies, a gain in efficiency in the construction sector is seen as an important opportunity for EC reduction (e.g. Upton et al., 2008; Monahan and Powell, 2011; Sandanayake et al., 2016). This is often intended as a more efficient manufacture of building materials, the use of innovative and less wasteful processes during the construction stage, or a combination of the two. This strategy also includes the reduction of delays, the impact of site conditions, and the use of more energy efficient machinery.

\subsection{MS13: carbon mitigation offsets, emissions trading, and carbon} $\operatorname{tax}$

Some scholars see the solution to the EC problem in carbon mitigation and trading, and in fewer cases carbon taxing. For instance, Dalene (Dalene, 2012) reports on a case study of a residential building where all "GHG emissions were offset by carbon mitigation programs and certified carbon offsets were purchased" to achieve carbon neutral status. At a broader scale, Kennedy and Sgouridis (Kennedy and Sgouridis, 2011) developed a carbon accounting framework for cities to categorise and determine urban emissions strategies.

\subsection{MS14: carbon sequestration}

The carbon sequestration approach found in few studies (e.g. Gustavsson et al., 2006; Dhakal, 2010) is to some extent linked to the previous strategy but it deserves a separate category due to different underlying principles: while carbon offsets and emissions trading offer a policy solution to EC reduction, carbon sequestration looks at the technological side of the issue exploring new materials or innovative uses of existing ones to capture and store carbon. For instance, Sodagar and colleagues (Sodagar et al., 2011) studied the use of biotic materials in a social housing project in the UK and concluded that the carbon lock-up potential could reduce carbon emissions by $61 \%$ over the 60-year lifespan of the houses.

\subsection{MS15: extending the building's life}

Intuitively, extending a building's life span would delay and therefore reduce the EC associated with deconstruction and demolition, waste processing and rebuild. However, this strategy is only considered by a handful of studies in the existing literature (e.g. Densley Tingley and Davison, 2011; Toller et al., 2011; Yung and Chan, 2012). In some of the studies, this strategy does not simply consider aiming for a longer service life of the building but is also about designing the building with the necessary flexibility to be durable and adaptable.

\subsection{MS16: increased use of prefabricated elements/off-site manufacturing}

This category is somewhat linked to more efficient construction processes but due to a clear stream within the existing literature oriented towards off-site manufacturing and prefabrication it was coded separately. In some studies, the emission savings of this strategy alone have been quantified. For instance Mao and colleagues (Mao et al., 2013) found that semi-prefabrication would emit 3.2\% less than conventional construction. Off-site manufacturing has been also investigated in combination with other strategies (e.g. the use of low embodied carbon materials) such as in the case of Monahan and Powell (Monahan and Powell, 2011).

\subsection{MS17: demolition and rebuild}

In a very few cases, such as Dubois and Allacker (Dubois and Allacker, 2015), it has been suggested that a truly significant carbon reduction in the built environment would only be achievable through wide campaigns of demolition and reconstruction with the belief that embodied costs of such activities are negligible compared to the benefits of new build. In another study (Boardman, 2007), a demolition level higher than current practice is considered a "sensible compromise" to tackle climate change.

\section{Meta-analysis and discussion}

This section analyses and interpolates data from the systematic literature review presented so far. As such, it can be regarded as that which Glass (Glass, 1976) defines as 'secondary analysis' or 'meta-analysis'. However while secondary analysis involves "the re-analysis of data for the purpose of answering new [research] questions with old data", meta-analysis is understood as "the analysis of results from individual studies for the purpose of integrating the findings" (Glass, 1976), which is the purpose of this section.

As a starting point, Table 3 maps the geographical amplitude and scope of the articles reviewed. Such two elements have been ap-

Table 3

Geographical Amplitude and Scope of the articles reviewed.

\begin{tabular}{lll}
\hline & GA (geographical amplitude) & SS (scope of the study) \\
\hline 0 & $15(13 \%)$ & $(18 \%)$ \\
1 & $14(12.2 \%)$ & $(36.7 \%)$ \\
2 & $74(64.3 \%)$ & $(12.5 \%)$ \\
3 & $12(10.4 \%)$ & $(32.8 \%)$ \\
\hline
\end{tabular}

GA: $\mathbf{0}=$ not related to geographical areas; $\mathbf{1}=$ super-country level; $\mathbf{2}=$ country level; $\mathbf{3}=$ sub-country level $-\mathbf{S S}$ : $\mathbf{0}=$ supra-context level; $\mathbf{1}=$ context level (building); $\mathbf{2}=$ system level; $\mathbf{3}=$ component level. 
proached and reviewed systemically, and the clustering system used goes from macro (e.g. super-country level) to micro (e.g. regional level). However, the vast majority $(64.3 \%)$ of the studies focus on single countries, while very few (10.4\%) consider wider geographical areas or single regions within a country. This may reflect how specific the built environment is from country to country, suggesting that a nation-wide approach is the preferred option when addressing embodied carbon issues to realistically consider the peculiarities of different contexts.

Things change for the scope of the studies and the meta-analysis reveals that most consider either buildings as a whole $(36.7 \%)$ or break them down to single-material level (32.8\%). Fewer studies $(12.5 \%)$ have considered macro-assemblies such as façades or roofs. However it is important to note the amount of literature $(18 \%)$ that has focussed on neighbourhoods, cities or - in some cases - the whole construction sector within a country.

Fig. 2 shows the analysis of temporal trend of published literature in the field. It is clear that academic interest around the topic is growing steadily and it may be that major international events or outcomes related to climate change (such as the United Nations Climate Change Conferences COP16 and COP19 and the IPCC reports of 2007 and 2014) could have fuelled research activity.

Fig. 3 shows the occurrence and the cumulative percentage of the number of different mitigation strategies considered in the literature reviewed for this research.

Most studies (more than $60 \%$ as shown in Fig. 3) consider less than four mitigation strategies -the biggest bulk being within two and

Temporal trend

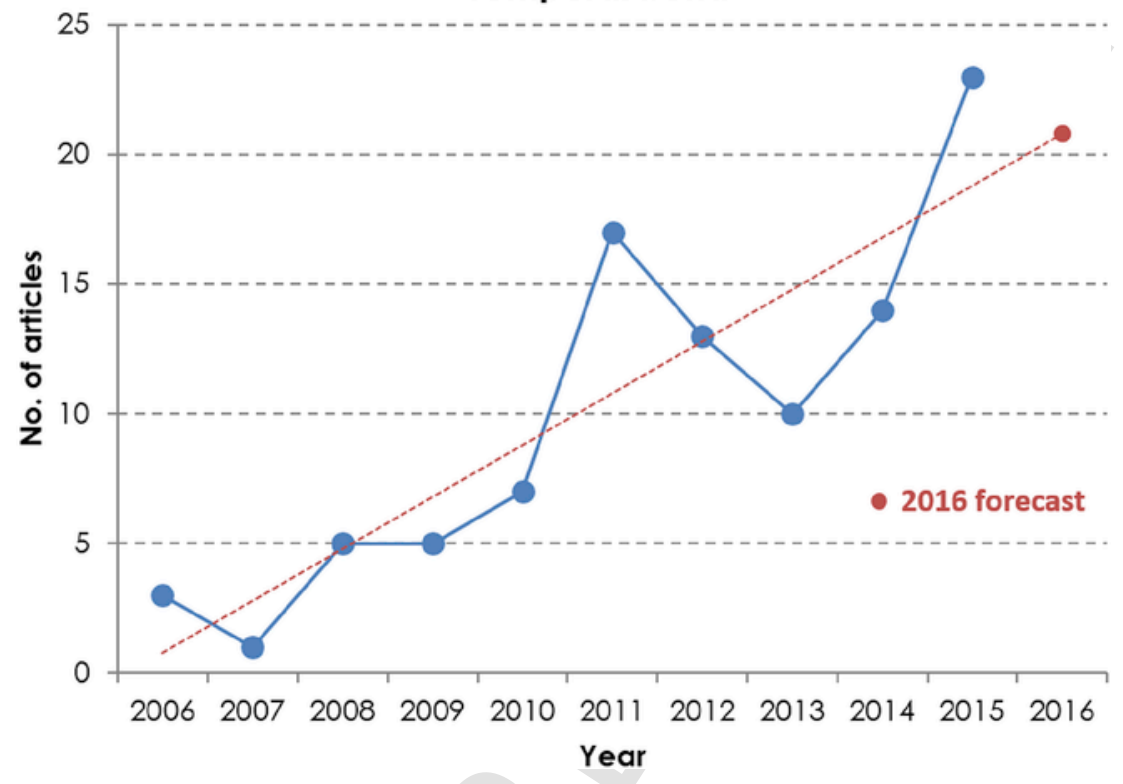

Fig. 2. Temporal trend of published literature in the subject.

\section{How many mitigation strategies?}

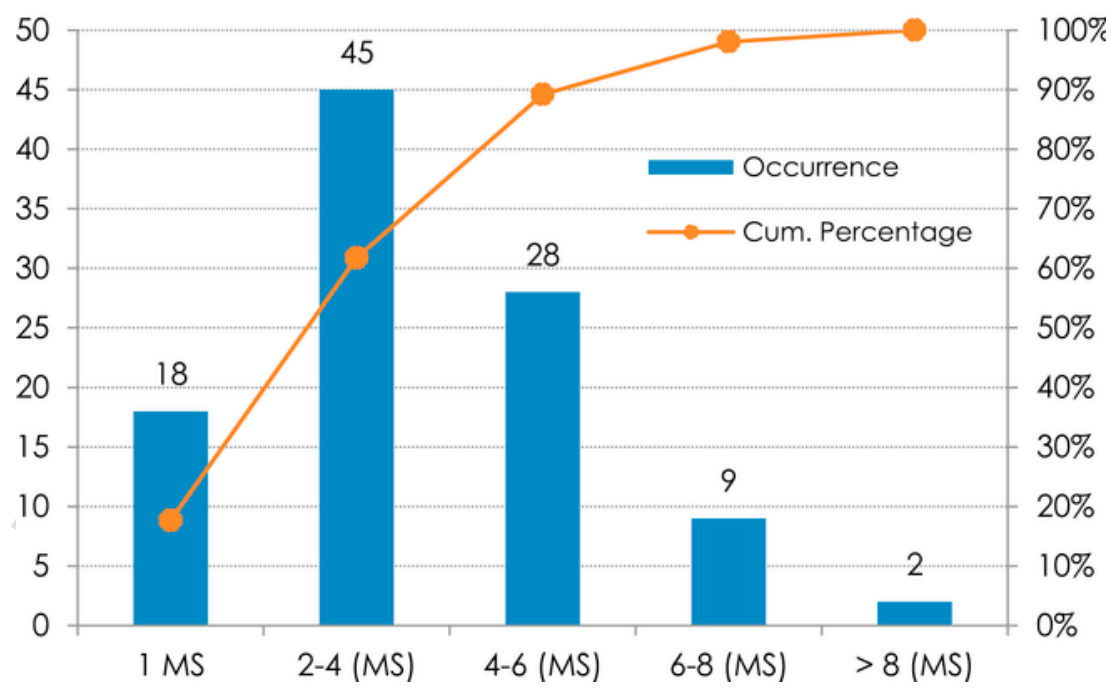

Fig. 3. Number of mitigation strategies (MS) in the studies reviewed. 
four - whereas just around $10 \%$ consider more than six. Given the fact that the majority of the studies suggest a focus on few strategies, if we consider embodied carbon as a 'problem' and the mitigation strategies as 'solutions' it is useful to use a Pareto chart to highlight this (Fig. 4). It can be seen that the usual 80/20 ratio typical of Pareto charts is not found here and more than half of the mitigation strategies are necessary to get to an $80 \%$ value.

A further element of interest regarding mitigation strategies is how they are mutually combined. Due to space limit and length requirements, such information is given in Table S1 and Table S2 of the supplementary material attached to this article.

The correlation analysis shows, for instance, that in nearly half of the cases when MS1 is proposed, MS2 is also mentioned, which indicates that the use of materials with lower EC is a design issue. In turn, MS2 occurs in $48 \%$ of the cases together with MS3 suggesting a key role of design in both promoting low EC materials and reducing the use of high EC ones. It should be noted that MS4 (new tools, methods, and methodologies) correlates almost solely with policies, either government led (MS4) or promoted by the construction sector (MS10). The correlation matrix in the supplementary material helps interpret the results of the meta-analysis. It is also noteworthy how the social 'component' (i.e. MS11, change driven by strong demand from all built environment stakeholders) shows higher correlation with both policies strategies (MS5 and MS10), a wider use of local materials (MS9) as well as the inclusion of waste and by-products into buildings (MS8).

The meta-analysis also gives useful insights into the details of the life cycle stages. Two main pieces of information are plotted in Fig. 5 and Fig. 6 respectively: first the number of life cycle stages considered in the studies; and second, which life cycle stages are considered (following the coding and terminology of TC350 standards (BSI, 2011) - see Fig. 1).

Fig. 5 demonstrates the partial nature of current LCA research, with $50 \%$ of the studies considering less than $40 \%$ life cycle stages, and nearly $90 \%$ of the studies less than $60 \%$ of a building's life cycle stages. Only 3 out of 77 articles have taken into account more than $80 \%$ of the stages identified by the TC350 standards. Please note that the number of individual stages does not reflect the impact of each stage.

Fig. 6 reveals exactly which stages are most focused on in the literature. Most studies undertake a cradle-to-gate (stages A1 to A3), cradle-to-site (A1 to A4), or cradle-to-commissioning assessment (A1 to A5). Such a focus is both narrow and short sighted, as it accounts only for short-term embodied costs while neglecting those in the medium and long term.

Fig. 7 shows the occurrence of life cycle stages in the literature reviewed and they are ordered as would normally occur during a building's life cycle. What is interesting too is that the end of life stages $(\mathrm{C} 1-\mathrm{C} 4)$ and even post-end of life stage $\mathrm{D}$, are more often assessed than the embodied impacts during the in-use life of the building, as assessed in stages B1 - B5.

From the LCA literature, insights from the systematic review reveal a partial approach to buildings' life cycle. Over $90 \%$ of the LCA studies are cradle-to-gate analyses which neglect what happens once building's components have left the manufacturing plants. Data quality and reliability also emerged as a source of concern. Many studies utilise the ICE database of the University of Bath (Hammond and Jones, 2011) but there are doubts about the representativeness and accuracy of their findings within the UK, let alone other countries. In fewer cases (around 50\% of the studies) the assessment extends until the end of the construction stage; these still overlook the potentially

\section{Pareto analysis of EC mitigation/reduction strategies}

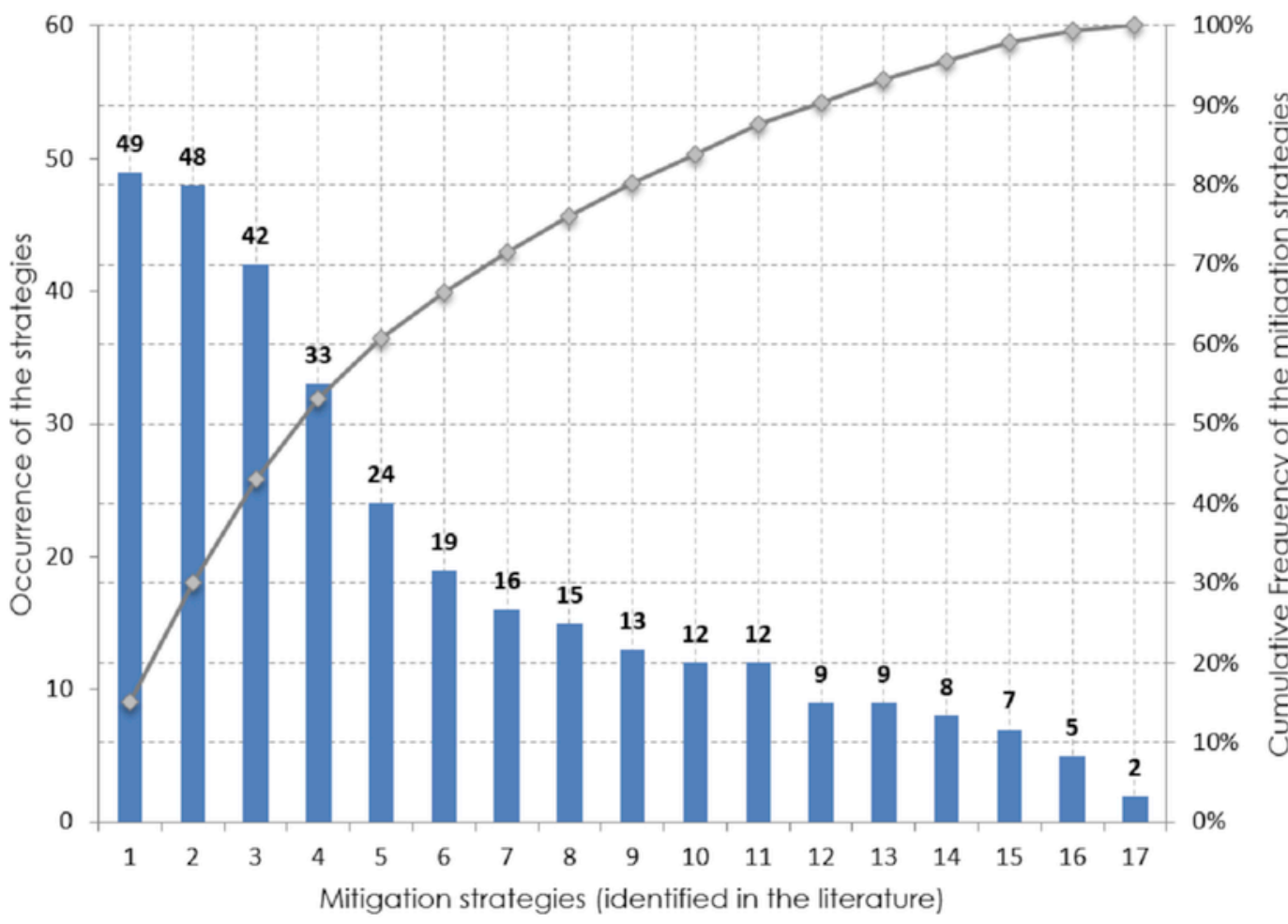

Fig. 4. Pareto chart of mitigation strategies (MS) identified in the literature. 


\section{Number of life cycle stages}

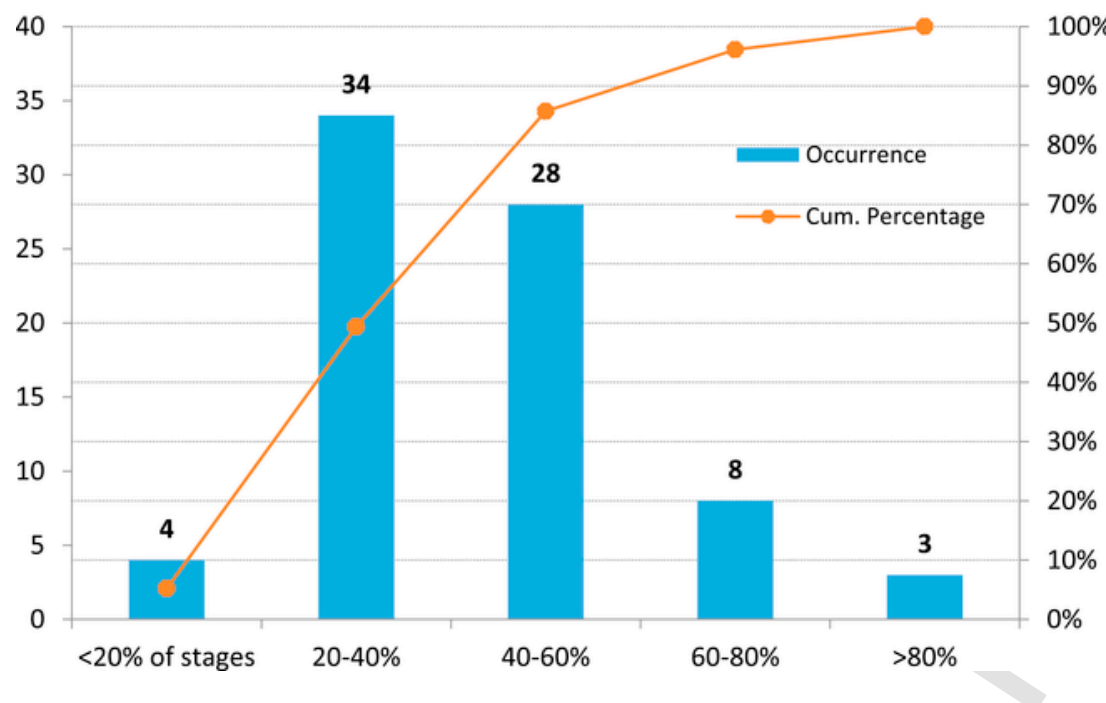

$100 \%$

$90 \%$

$80 \%$

$70 \%$

$60 \%$

$50 \%$

$40 \%$

$30 \%$

$20 \%$

$10 \%$

Fig. 5. Number of life cycle stages in the LCA articles reviewed.

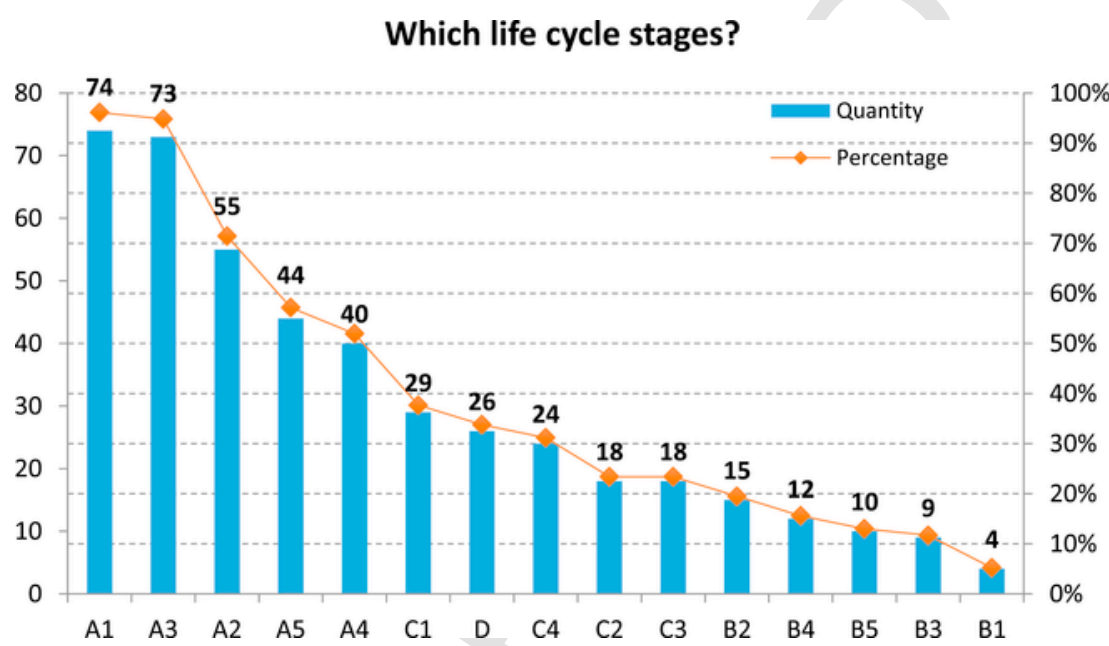

Fig. 6. Life cycle stages considered in the LCA articles reviewed (77 publications out of the 102) according to TC 350 coding and terminology.

substantial maintenance, replacement and repair activities that occur over the building's life. Indeed the B stages are the most neglected by current research, being considered by only $20 \%$ of the studies. The end of life stages (C and D) are accounted for in around 30\% of the studies examined. Additionally, these activities happen in a distant future and are therefore characterised by high uncertainty.

\section{Conclusions}

This article has systematically reviewed a substantial amount of existing academic knowledge on embodied carbon mitigation and reduction in the built environment and life cycle assessment of buildings.

The findings have highlighted the growing concern over the role of embodied carbon in the built environment. In total, 17 mitigation strategies have been identified which reveal a substantially diverse range of approaches to address the problem. Two main things clearly emerged from the analysis. Firstly, the problem requires a pluralistic solution because no single mitigation strategy is seen to be effective in EC reduction; indeed more than $80 \%$ of the reviewed studies rec- ommend more than one mitigation strategy. Secondly, the analysis has shown the interconnectedness of the role of the designer with those of the researchers, the materials manufacturers and the policy makers. For instance, the development and use of materials with low EC is intertwined with a better design which in turn is seen as the key element to also reduce, re-use and recover EC-intensive construction materials, such as steel and concrete. New tools, methods and methodologies are also needed to facilitate the transition to a low-carbon built environment, as are policies at both government and construction sector levels. These however require support from the society at large (social 'component') if a substantial change is to be achieved.

In developed countries, the upkeep of the existing building stock also stood out as a crucial element. In most cases, this was simply seen as the need to refurbish existing buildings although there are growing signs of more specific research activities in extending the building's life during a refurbishment project in a design-for-longevity aim. Interestingly, this aspect from the mitigation strategies analysis clashes with the assumed service life of buildings in the LCA literature reviewed, in which, for the vast majority of the arti- 
Which life cycle stages?

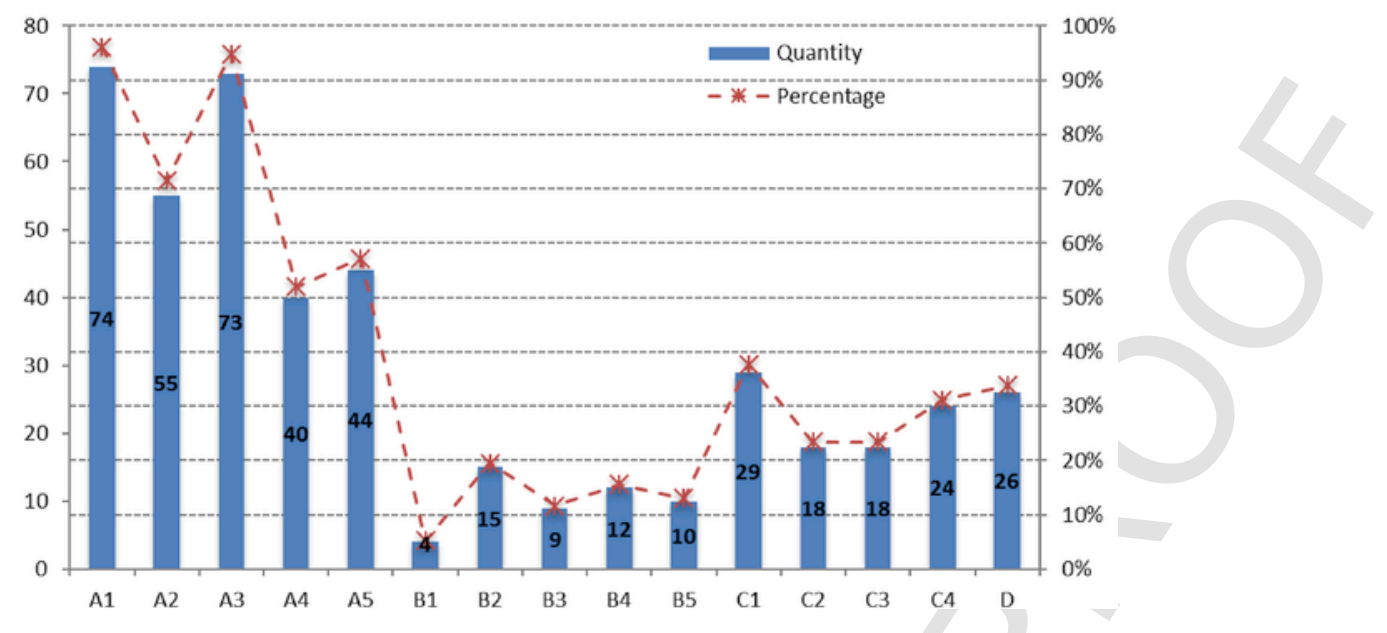

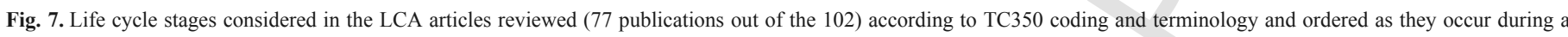
building's life cycle.

cles, buildings are assessed for a design life of 50 years. However the evidence around us says otherwise; in the UK, for instance, $80 \%$ of the buildings that will be standing in 2050 have already been built (Kelly, 2008) and the average lifespan is 132 years (Ma et al., 2015).

This research has also shown the current incompleteness of most LCAs. Over $90 \%$ of the LCA studies reviewed only look at the manufacturing stage whereas just over $50 \%$ go up to the end of the construction stage. Impacts occurring during the occupancy stage and at the end of life of a building are often totally overlooked. This requires extra care when using results from published LCAs, which might be both partial and short sighted. While incomplete assessment is better than no assessment at all (Hertwich et al., 2000), there is now the knowledge and potential to address and attempt to solve the current limitations, and the academic community have the responsibility to do so. Researchers should adopt a stricter terminology (and editors and reviewers should monitor this) and avoid to label as LCA what is often instead a cradle-to-gate assessment.

In conclusion, this research suggests that a pluralistic and multidisciplinary approach to EC reduction is imperative if a substantial change is to be achieved. It has also highlighted current shortcomings and challenges in LCA research and calls for a more comprehensive approach to buildings' life cycle as well as greater consideration for data quality and uncertainty. Work at the University of Cambridge will continue with such interdisciplinarity in mind to facilitate a quicker transition to a low carbon built environment.

\section{Limitations and further research}

The method used, i.e. a systematic review, might miss out on some literature that still fall within the scope and this can be seen as a limitation of this research. Such limitation is due to the objective approach in selecting publications - which is based on matching keywords rather than the subjective judgements of the authors. For instance, this could be the case of some of the-especially Nordic-literature on the use of materials with low EC that has not been addressed extensively here because it did not appear in the search results. It is however important to note that the systemic approach used goes from search strings to mitigation strategies through the identification of relevant literature, and not the other way around. Therefore, while the literature around each MS might not be necessarily exhaustive, the one related to the search strings certainly is.
Based on the findings, several avenues for further research can be identified. An interdisciplinary framework for collaboration amongst relevant stakeholders would benefit both the theory and practice of embodied carbon mitigation and management. Similarly, a comprehensive review of methods and methodologies available and their subsequent integration into a holistic and harmonised updated tool would be an extremely valuable contribution. The theme of existing buildings also certainly deserves further research as they perform often poorly in terms of operational energy consumption but have an embodied carbon capital embedded that should be more appropriately considered in the demolish vs. refurbish debate. Additionally, sensitivity and uncertainty analysis are seldom undertaken in LCAs in the built environment. Newer and simpler approaches are required to facilitate a wider use and a broader uptake of such fundamental components of an environmental impact assessment by both academics and practitioners.

Both qualitative and quantitative research on the actors involved with each MSs, from identification through mapping to interactions, also constitute important advancements in the discourse around the topic. Finally, a quantitative evaluation of the EC reduction potential of each MS if adopted on a large scale would be an incredibly insightful contribution to further knowledge in the field and help guide policy directions.

\section{Acknowledgements}

The authors wish to acknowledge the Isaac Newton Trust for funding this research. Grateful thanks also to the editor and reviewers for their constructive comments which helped improved both quality and clarity of the article.

\section{Appendix A. Supplementary data}

Supplementary data related to this article can be found at http://dx. doi.org/10.1016/j.jenvman.2016.08.036.

\section{References}

Acquaye, A.A., Duffy, A.P., 2010. Input-output analysis of Irish construction sector greenhouse gas emissions. Build. Environ. 45, 784-791.

Acquaye, A., Duffy, A., Basu, B., 2011. Embodied emissions abatement-A policy assessment using stochastic analysis. Energy Policy 39, 429-441. 
Akbarnezhad, A., Ong, K.C.G., Chandra, L.R., 2014. Economic and environmental assessment of deconstruction strategies using building information modeling. Automation Constr. 37, 131-144.

Alshamrani, O.S., Galal, K., Alkass, S., 2014. Integrated LCA-LEED sustainability assessment model for structure and envelope systems of school buildings. Build. Environ. 80, 61-70.

Ardente, F., Beccali, M., Cellura, M., Mistretta, M., 2008. Building energy performance: a LCA case study of kenaf-fibres insulation board. Energy Build. 40, 1-10.

Ariyaratne, C.I., Moncaster, A.M., 2014. Stand-alone calculation tools are not the answer to embodied carbon assessment. Energy Procedia 62, 150-159.

Asdrubali, F., Baldinelli, G., D'Alessandro, F., Scrucca, F., 2015. Life cycle assessment of electricity production from renewable energies: review and results harmonization. Renew. Sustain. Energy Rev. 42, 1113-1122.

Asdrubali, F., D'Alessandro, F., Schiavoni, S., 2015. A review of unconventional sustainable building insulation materials. Sustain. Mater. Technol. 4, 1-17.

ASPB, 2014. Embodied Carbon Industry Task Force Recommedations - Proposals for Standardised Measurement Method and Recommendations for Zero Carbon Build ing Regulations and Allowable Solutions. The Alliance for Sustainable Building Products. http://www.asbp.org.uk/uploads/documents/resources/ Embodied\%20Carbon\%20Indusrty\%20Task\%20Force\%20Proposals June \%202014 Final\%5B1\%5D.pdf.

Atmaca, A., Atmaca, N., 2015. Life cycle energy (LCEA) and carbon dioxide emissions (LCCO2A) assessment of two residential buildings in Gaziantep, Turkey. Energy Build. 102, 417-431.

Baek, C., Park, S.-H., Suzuki, M., Lee, S.-H., 2013. Life cycle carbon dioxide assessment tool for buildings in the schematic design phase. Energy Build. 61, 275-287.

Basbagill, J., Flager, F., Lepech, M., Fischer, M., 2013. Application of life-cycle assessment to early stage building design for reduced embodied environmental impacts. Build. Environ. 60, 81-92.

Bin, G., Parker, P., 2012. Measuring buildings for sustainability: comparing the initial and retrofit ecological footprint of a century home-The REEP House. Appl. Energy 93, 24-32.

Biswas, W., 2014. Carbon footprint and embodied energy assessment of a civil works program in a residential estate of Western Australia. Int. J. Life Cycle Assess. 19, $732-744$.

Biswas, W.K., 2014. Carbon footprint and embodied energy consumption assessment of building construction works in Western Australia. Int. J. Sustain. Built Environ. $3,179-186$

Blengini, G.A., Di Carlo, T., 2010. Energy-saving policies and low-energy residential buildings: an LCA case study to support decision makers in Piedmont (Italy). Int. J. Life Cycle Assess. 15, 652-665.

Boardman, B., 2007. Examining the carbon agenda via the $40 \%$ House scenario. Build Res. Inf. 35, 363-378.

Brás, A., Gomes, V., 2015. LCA implementation in the selection of thermal enhanced mortars for energetic rehabilitation of school buildings. Energy Build. 92, 1-9.

BRE, 2015. The Green Guide Explained. BRE Centre for Sustainable Products. Building Research Establishment. http://www.bre.co.uk/filelibrary/greenguide/PDF/ The-Green-Guide-Explained_March2015.pdf.

Bribián, I.Z., Capilla, A.V., Usón, A.A., 2011. Life cycle assessment of building materials: comparative analysis of energy and environmental impacts and evaluation of the eco-efficiency improvement potential. Build. Environ. 46, 1133-1140.

Brown, N.W.O., Olsson, S., Malmqvist, T., 2014. Embodied greenhouse gas emission from refurbishment of residential building stock to achieve a $50 \%$ operational energy reduction. Build. Environ. 79, 46-56.

BSI, 2011. Sustainability of Construction Works - Assessment of Environmental Performance of Buildings - Calculation Method. BS EN 15978:2011.

Cabeza, L.F., Barreneche, C., Miró, L., Morera, J.M., Bartolí, E., Inés Fernández, A., 2013. Low carbon and low embodied energy materials in buildings: a review. Renew. Sustain. Energy Rev. 23, 536-542.

Chang, Y., Ries, R.J., Wang, Y., 2011. The quantification of the embodied impacts of construction projects on energy, environment, and society based on I-O LCA. Energy Policy 39, 6321-6330.

Chau, C.K., Hui, W.K., Ng, W.Y., Powell, G., 2012. Assessment of CO2 emissions reduction in high-rise concrete office buildings using different material use options. Resour. Conservation Recycl. 61, 22-34.

Chou, J.-S., Yeh, K.-C., 2015. Life cycle carbon dioxide emissions simulation and environmental cost analysis for building construction. J. Clean. Prod. 101, 137-147.

Crawford, R.H., 2011. Life Cycle Assessment in the Built Environment. Spon Press, London, New York.

Crishna, N., Banfill, P.F.G., Goodsir, S., 2011. Embodied energy and CO2 in UK dimension stone. Resour. Conservation Recycl. 55, 1265-1273.

Cuéllar-Franca, R.M., Azapagic, A., 2012. Environmental impacts of the UK residential sector: life cycle assessment of houses. Build. Environ. 54, 86-99.
Cui, H.Z., Sham, F.C., Lo, T.Y., Lum, H.T., 2011. Appraisal of alternative building materials for reduction of $\mathrm{CO} 2$ emissions by case modeling. Int. J. Environ. Res. 5, 93-100.

Culakova, M., Vilcekova, S., Burdova, E.K., Katunska, J., 2012. Reduction of carbon footprint of building structures. In: Varbanov, P.S., Lam, H.L., Klemes, J.J., Pierucci, S., Klemes, J.J. (Eds.), 15th International Conference on Process Integration, Modelling and Optimisation for Energy Saving and Pollution Reduction2012. pp. 199-204.

Dakwale, V.A., Ralegaonkar, R.V., Mandavgane, S., 2011. Improving environmental performance of building through increased energy efficiency: a review. Sustain. Cities Soc. 1, 211-218.

Dalene, F., 2012. Technology and information management for low-carbon building. J. Renew. Sustain. Energy 4.

Delbufalo, E., 2012. Outcomes of inter-organizational trust in supply chain relationships: a systematic literature review and a meta-analysis of the empirical evidence. Supply Chain Manag. Int. J. 17, 377-402.

Densley Tingley, D., Davison, B., 2011. Design for deconstruction and material reuse. Proc. Institution Civ. Engineers-Energy 164, 195-204.

Dhakal, S., 2010. GHG emissions from urbanization and opportunities for urban carbon mitigation. Curr. Opin. Environ. Sustain. 2, 277-283

Dixit, M.K., Fernandez-Solis, J.L., Lavy, S., Culp, C.H., 2012. Need for an embodied energy measurement protocol for buildings: a review paper. Renew. Sust. Energ Rev. 16, 3730-3743

Dubois, M., Allacker, K., 2015. Energy savings from housing: ineffective renovation subsidies vs efficient demolition and reconstruction incentives. Energy Policy $86,697-704$

EC, 2011. Roadmap to a Resource Efficient Europe - Communication from the Commission to the European Parliament, the Council, the European Economic and Social Committee and the Committee of the Regions COM(2011) 571 Final. European Commission.

EEA, 2012. Material Resources and Waste - 2012 Update. European Environment Agency, Copenhagen.

EU, 2010. Directive 2010/31/EU of the European parliament and of the council of 19 may 2010 on the energy performance of buildings (recast). Official J. Eur. Union p. L153/13-L/35.

Foraboschi, P., Mercanzin, M., Trabucco, D., 2014. Sustainable structural design of tall buildings based on embodied energy. Energy Build. 68, 254-269. Part A.

Fu, F., Luo, H., Zhong, H., Hill, A., 2014. Development of a carbon emission calculations system for optimizing building plan based on the LCA framework. Math. Problems Eng.

Fu, F., Sun, J., Pasquire, C., 2015. Carbon emission assessment for steel structure based on lean construction process. J. Intelligent Robotic Syst. 79, 401-416.

Garcia-Segura, T., Yepes, V., Alcala, J., 2014. Life cycle greenhouse gas emissions of blended cement concrete including carbonation and durability. Int. J. Life Cycle Assess. 19, 3-12.

Gaspar, P.L., Santos, A.L., 2015. Embodied energy on refurbishment vs. demolition: a Southern Europe case study. Energy Build. 87.

Gavotsis, E., Moncaster, A.M., 2015. Improved embodied energy and carbon accounting: recommendations for industry and policy. Athens J. Technol. Eng. 2, 9-23.

Giesekam, J., Barrett, J., Taylor, P., Owen, A., 2014. The greenhouse gas emissions and mitigation options for materials used in UK construction. Energy Build. 78, 202-214.

Giesekam, J., Barrett, J., Taylor, P., 2015. Construction sector views on low carbon building materials. Build. Res. Inf.

Girod, B., 2016. Product-oriented climate policy: learning from the past to shape the future. J. Clean. Prod.http://dx.doi.org/10.1016/j.jclepro.2015.07.010.

Glass, G.V., 1976. Primary, secondary, and meta-analysis of research. Educ. Res. 5, 3-8.

Gong, X., Nie, Z., Wang, Z., Cui, S., Gao, F., Zuo, T., 2012. Life cycle energy consumption and carbon dioxide emission of residential building designs in Beijing a comparative study. J. Ind. Ecol. 16, 576-587.

Gustavsson, L., Sathre, R., 2006. Variability in energy and carbon dioxide balances of wood and concrete building materials. Build. Environ. 41, 940-951.

Gustavsson, L., Pingoud, K., Sathre, R., 2006. Carbon dioxide balance of wood substitution: comparing concrete-and wood-framed buildings. Mitig. Adapt. strategies Glob. change 11,667-691.

Gustavsson, L., Joelsson, A., Sathre, R., 2010. Life cycle primary energy use and carbon emission of an eight-storey wood-framed apartment building. Energy Build. 42, 230-242.

Häkkinen, T., Kuittinen, M., Ruuska, A., Jung, N., 2015. Reducing embodied carbon during the design process of buildings. J. Build. Eng. 4, 1-13.

Hamilton-MacLaren, F., Loveday, D.L., Mourshed, M., 2013. Public opinions on alternative lower carbon wall construction techniques for UK housing. Habitat Int. 37, 163-169.

Hammond, G., Jones, C., 2011. Embodied Carbon: the Inventory of Carbon and Energy (ICE). University of Bath and BSRIA. BG 10/2011.

Heinonen, J., Saynajoki, A., Junnila, S., 2011. A longitudinal study on the carbon emissions of a new residential development. Sustainability 3, 1170-1189. 
Heinonen, J., Säynäjoki, A., Junnonen, J.-M., Pöyry, A., Junnila, S., 2016. Pre-use phase LCA of a multi-story residential building: can greenhouse gas emissions be used as a more general environmental performance indicator?. Build. Environ. 95, 116-125.

Hertwich, E.G., Hammitt, J.K., Pease, W.S., 2000. A theoretical foundation for life-cycle assessment. J. Ind. Ecol. 4, 13-28.

Hou, S., Li, H., Rezgui, Y., 2015. Ontology-based approach for structural design considering low embodied energy and carbon. Energy Build. 102, 75-90.

Ibn-Mohammed, T., Greenough, R., Taylor, S., Ozawa-Meida, L., Acquaye, A., 2013. Operational vs. embodied emissions in buildings-A review of current trends. Energy Build. 66, 232-245

ICE, 2015. Energy Briefing Sheet: Embodied Energy and Carbon. Institution of Civil Engineers. https://www.ice.org.uk/disciplines-and-resources/briefing-sheet/ embodied-energy-and-carbon.

Iddon, C.R., Firth, S.K., 2013. Embodied and operational energy for new-build housing: a case study of construction methods in the UK. Energy Build. 67, 479-488.

IEA, 2014. Technology Roadmap. Energy Efficient Building Envelopes. International Energy Agency, Paris, France.

IEA, 2016. Annex 57 Evaluation of Embodied Energy \& Embodied GHG Emissions for Building Construction - Report of Subtask 4: Recommendations for the Reduction of Embodied Carbon and Energy from Buildings. International Energy Agency.

Ingrao, C., Lo Giudice, A., Bacenetti, J., Tricase, C., Dotelli, G., Fiala, M., et al., 2015. Energy and environmental assessment of industrial hemp for building applications: a review. Renew. Sustain. Energy Rev. 51, 29-42.

Intini, F., Kuehtz, S., 2011. Recycling in buildings: an LCA case study of a thermal insulation panel made of polyester fiber, recycled from post-consumer PET bottles. Int. J. Life Cycle Assess. 16, 306-315.

IPCC, 2014. Intergovernmental Panel on Climate Change - Climate Change 2014: Impacts, Adaptation, and Vulnerability. Cambridge University Press, Cambridge, UK; New York, NY, USA.

Jang, M., Hong, T., Ji, C., 2015. Hybrid LCA model for assessing the embodied environmental impacts of buildings in South Korea. Environ. Impact Assess. Rev. 50, 143-155.

Jiang, P., Tovey, N.K., 2009. Opportunities for low carbon sustainability in large commercial buildings in China. Energy Policy 37, 4949-4958.

Kelly, M.J., 2008. Britain's Building Stock - a Carbon Challenge. Communities and Local Government. University of Cambridge.

Kennedy, S., Sgouridis, S., 2011. Rigorous classification and carbon accounting principles for low and Zero Carbon Cities. Energy Policy 39, 5259-5268.

Khasreen, M., Banfill, P.F., Menzies, G., 2009. Life-cycle assessment and the environmental impact of buildings: a review. Sustainability 1, 674-701.

Lee, K., Tae, S., Shin, S., 2009. Development of a life cycle assessment program for building (SUSB-LCA) in South Korea. Renew. Sustain. Energy Rev. 13, 1994-2002.

Lee, B., Trcka, M., Hensen, J.L., 2011. Embodied energy of building materials and green building rating systems - a case study for industrial halls. Sustain. Cities Soc. $1,67-71$.

Li, J., Colombier, M., 2009. Managing carbon emissions in China through building energy efficiency. J. Environ. Manage 90, 2436-2447.

Li, D.Z., Chen, H.X., Hui, E.C.M., Zhang, J.B., Li, Q.M., 2013. A methodology for estimating the life-cycle carbon efficiency of a residential building. Build. Environ. 59, 448-455

Ma, J.-J., Liu, L.-Q., Su, B., Xie, B.-C., 2015. Exploring the critical factors and appropriate polices for reducing energy consumption of China's urban civil building sector. J. Clean. Prod. 103, 446-454.

Mao, C., Shen, Q., Shen, L., Tang, L., 2013. Comparative study of greenhouse gas emissions between off-site prefabrication and conventional construction methods: two case studies of residential projects. Energy Build. 66, 165-176.

Miller, D., Doh, J.-H., 2015. Incorporating sustainable development principles into building design: a review from a structural perspective including case study. Struct. Des. Tall Special Build. 24, 421-439.

Monahan, J., Powell, J.C., 2011. An embodied carbon and energy analysis of modern methods of construction in housing: a case study using a lifecycle assessment framework. Energy Build. 43, 179-188.

Moncaster, A., 2015. Pathways to low carbon building: reflection on the special issue. Buildings 5, 751.

Moncaster, A.M., Song, J.Y., 2012. A comparative review of existing data and methodologies for calculating embodied energy and carbon of buildings. Int. J. Sustain. Build. Technol. Urban Dev. 3, 26-36.

Moncaster, A.M., Symons, K.E., 2013. A method and tool for 'cradle to grave' embodied carbon and energy impacts of UK buildings in compliance with the new TC350 standards. Energy Build. 66, 514-523.

Moussavi Nadoushani, Z.S., Akbarnezhad, A., 2015. Effects of structural system on the life cycle carbon footprint of buildings. Energy Build. 102, 337-346.

Moynihan, M.C., Allwood, J.M., 2014. Utilization of structural steel in buildings. Proc. R. Soc. a-Mathematical Phys. Eng. Sci. 470
Napolano, L., Menna, C., Asprone, D., Prota, A., Manfredi, G., 2015. LCA-based study on structural retrofit options for masonry buildings. Int. J. Life Cycle Assess. 20, 23-35.

Naustdalslid, J., 2014. Circular economy in China - the environmental dimension of the harmonious society. Int. J. Sustain. Dev. World Ecol. 21, 303-313.

Ng, S.T., Wong, J.M.W., Skitmore, S., Veronika, A., 2012. Carbon dioxide reduction in the building life cycle: a critical review. Proc. Institution Civ. Engineers-Engineering Sustain. 165, 281-292.

Norman, J., MacLean, H.L., Kennedy, C.A., 2006. Comparing high and low residential density: life-cycle analysis of energy use and greenhouse gas emissions. J. urban Plan. Dev. 132, 10-21

Onat, N.C., Kucukvar, M., Tatari, O., 2014. Scope-based carbon footprint analysis of US residential and commercial buildings: an input-output hybrid life cycle assessment approach. Build. Environ. 72, 53-62.

Peng, C., 2016. Calculation of a building's life cycle carbon emissions based on Ecotect and building information modeling. J. Clean. Prod.

Pomponi, F., Piroozfar, P.A.E., Southall, R., Ashton, P., Farr, E.R.P., 2015. Life cycle energy and carbon assessment of double skin façades for office refurbishments. Energy Build. 109, 143-156.

Pomponi, F., Piroozfar, P.A.E., Farr, E.R.P., 2016. An investigation into GHG and non-GHG impacts of double skin façades in office refurbishments. J. Ind. Ecol. 20 234-248.

Pomponi, F., Piroozfar, P.A.E., Southall, R., Ashton, P., Farr, E.R.P., 2016. Energy performance of Double-Skin Façades in temperate climates: a systematic review and meta-analysis. Renew. Sustain. Energy Rev. 54, 1525-1536.

Power, A., 2008. Does demolition or refurbishment of old and inefficient homes help to increase our environmental, social and economic viability?. Energy Policy $36,4487-4501$.

Power, A., 2010. Housing and sustainability: demolition or refurbishment?. Proc. ICE-Urban Des. Plan. 163, 205-216.

Purnell, P., 2012. Material nature versus structural nurture: the embodied carbon of fundamental structural elements. Environ. Sci. Technol. 46, 454-461.

Purnell, P., 2013. The carbon footprint of reinforced concrete. Adv. Cem. Res. 25, 362-368.

Reddy, B.V., 2009. Sustainable materials for low carbon buildings. Int. J. Low-Carbon Technol. 4, 175-181.

Renger, B.C., Birkeland, J.L., Midmore, D.J., 2015. Net-positive building carbon sequestration. Build. Res. Inf. 43, 11-24.

RICS, 2012. Methodology to Calculate Embodied Carbon of Materials - RICS Information Paper. Produced by the Embodied Carbon Working Group of the Royal Institution of Chartered Surveyors. London.

Roberts, S., 2008. Effects of climate change on the built environment. Energy Policy $36,4552-4557$

Rossi, B., Marique, A.-F., Glaumann, M., Reiter, S., 2012. Life-cycle assessment of residential buildings in three different European locations, basic tool. Build. Environ. 51 .

Rovers, R., 2014. Zero-energy and beyond: a paradigm shift in assessment. Buildings 5,1 .

Salazar, J., Meil, J., 2009. Prospects for carbon-neutral housing: the influence of greater wood use on the carbon footprint of a single-family residence. J. Clean Prod. 17, 1563-1571

Sandanayake, M., Zhang, G., Setunge, S., 2016. Environmental emissions at foundation construction stage of buildings - two case studies. Build. Environ. 95, 189-198.

Santero, N., Loijos, A., Ochsendorf, J., 2013. Greenhouse gas emissions reduction opportunities for concrete pavements. J. Ind. Ecol. 17, 859-868.

Seyfang, G., 2010. Community action for sustainable housing: building a low-carbon future. Energy Policy 38, 7624-7633.

Sodagar, B., Rai, D., Jones, B., Wihan, J., Fieldson, R., 2011. The carbon-reduction potential of straw-bale housing. Build. Res. Inf. 39, 51-65.

Song, D., Su, M., Yang, J., Chen, B., 2012. Greenhouse gas emission accounting and management of low-carbon community. Sci. World J.

Toller, S., Wadeskog, A., Finnveden, G., Malmqvist, T., Carlsson, A., 2011. Energy use and environmental impacts of the swedish building and real estate management sector. J. Ind. Ecol. 15, 394-404

Tranfield, D.R., Denyer, D., Smart, P., 2003. Towards a methodology for developing evidence-informed management knowledge by means of systematic review. Br. J. Manag. 14, 207-222.

Turconi, R., Boldrin, A., Astrup, T., 2013. Life cycle assessment (LCA) of electricity generation technologies: overview, comparability and limitations. Renew. Sustain. Energy Rev. 28, 555-565.

UKGBC, 2015. Tackling Embodied Carbon in Buildings. Campaign for a Sustainable Built Environment. UK Green Building Council

UN, 2016. Sustainable Development Goals - Goal 11: Make Cities Inclusive, Safe, Resilient and Sustainable.

Upton, B., Miner, R., Spinney, M., Heath, L.S., 2008. The greenhouse gas and energy impacts of using wood instead of alternatives in residential construction in the United States. Biomass Bioenergy 32, 1-10. 
Vukotic, L., Fenner, R.A., Symons, K., 2010. Assessing embodied energy of building structural elements. Proc. Institution Civ. Engineers-Engineering Sustain. 163, 147-158.

Xie, X., Cai, W., Jiang, Y., Zeng, W., 2015. Carbon footprints and embodied carbon flows analysis for China's eight regions: a new perspective for mitigation solutions. Sustainability 7, 10098-10114.

Xing, S., Xu, Z., Jun, G., 2008. Inventory analysis of LCA on steel- and concrete-construction office buildings. Energy Build. 40, 1188-1193.

Yeo, D., Gabbai, R.D., 2011. Sustainable design of reinforced concrete structures through embodied energy optimization. Energy Build. 43, 2028-2033.

You, F., Hu, D., Zhang, H., Guo, Z., Zhao, Y., Wang, B., et al., 2011. Carbon emissions in the life cycle of urban building system in China-A case study of residential buildings. Ecol. Complex. 8, 201-212.
Yu, D., Tan, H., Ruan, Y., 2011. A future bamboo-structure residential building prototype in China: life cycle assessment of energy use and carbon emission. Energy Build. 43, 2638-2646.

Yung, E.H., Chan, E.H., 2012. Implementation challenges to the adaptive reuse of heritage buildings: towards the goals of sustainable, low carbon cities. Habitat Int. 36, 352-361.

Zaid, A., Paul, J., 2014. The importance of embodied energy in carbon footprint assessmentnull. Struct. Surv. 32, 49-60.

Zhang, X., Wang, F., 2015. Life-cycle assessment and control measures for carbon emissions of typical buildings in China. Build. Environ. 86, 89-97. 